\title{
Laparoscopic hysterectomy experience and learning curve: in our clinic
}

\section{Kliniğimizdeki laparoskopik histerektomi deneyimimiz ve öğrenme eğrisi}

\author{
Gökmen Sulkgen ${ }^{1}$, Ůnal Türrkay ${ }^{2}$
}

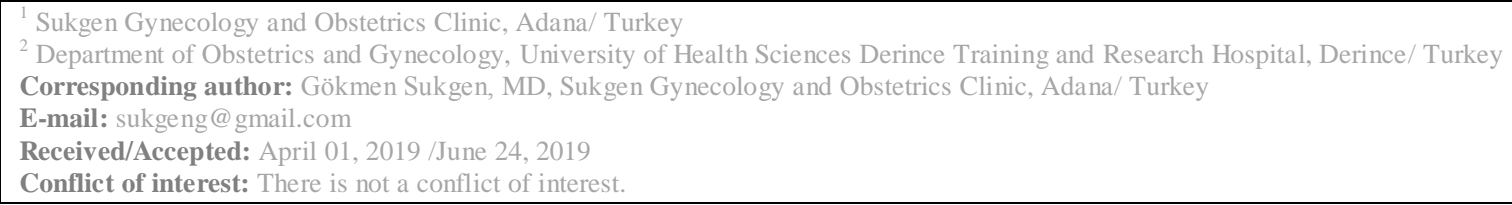

\section{SUMMARY}

Objective: The aim of this article is to compare the perioperative results of 30 laparoscopic hysterectomies (LH) and $62 \mathrm{LH}$ operations performed on patients in similar age groups and demographic characteristics.

Method: A total of 92 patients who were operated between September 2013 and June 2015 in our clinic were included in the study. Group 1 was formed with the first 30 patients who underwent LH surgery for the first time. Group 2 was formed with 62 patients.

Results: No statistically significant difference was found between the patients in Group 1 and Group 2 in terms of age, number of parity and previous pelvic surgery history $(\mathrm{p}=0.845 ; \mathrm{p}=0.266$, and $\mathrm{p}=0.796)$. There was also no statistically significant difference between the patients in Group 1 and Group 2 in terms of operation time (min.), Delta $\mathrm{Hb}$ ( $\mathrm{gr} / \mathrm{dl}$ ), hospitalization time (day) and complication rate $(\mathrm{p}=0.198 ; \mathrm{p}=0.486 ; \mathrm{p}=$ 0.201 , and $\mathrm{p}=0.454)$.

Conclusions: Although laparoscopic hysterectomy is an operation method with low complication rates and high patient satisfaction, it should be kept in mind that increased surgical experience does not always guarantee good perioperative results.

Keywords: Experience, hysterectomy, laparoscopic, pelvic surgery, vaginal hysterectomy
Gökmen Sukgen

Ünal Türkay

ORCID IDs of the authors:

G.S. 0000-0002-1597-2799

Ü.T. 0000-0002-9370-6816

\section{ÖZET}

Amaç: Bu makalenin amacı, 30 laparoskopik histerektominin (LH) ve benzer yaş gruplarındaki hastalarda yapılan 62 LH ameliyatının perioperatif sonuçlarını ve demografik özelliklerini karşılaştırmaktır.

Yöntem: Eylül 2013 - Haziran 2015 tarihleri arasında kliniğimizde opere edilen toplam 92 hasta çalışmaya dâhil edilmiștir. İlk kez LH ameliyatı geçiren ilk 30 hasta ile Grup 1 olușturulmuştur. Grup 2 ise 62 hasta ile olușturulmuștur. Bulgular: Grup 1 ve Grup 2'deki hastalar arasında yaş, parite sayısı ve önceki pelvik cerrahi öyküsü açısından istatistiksel olarak anlamlı fark bulunmamıstır $(\mathrm{p}=0.845 ; \mathrm{p}=0.266$, and $\mathrm{p}=0.796)$. Grup 1 ve Grup 2'deki hastalar arasında operasyon süresi (dk.), Delta $\mathrm{Hb}$ (gr / dl), hastanede yatış süresi (gün) ve komplikasyon oranı açısından istatistiksel olarak anlaml fark yoktur $(\mathrm{p}=0.198 ; \mathrm{p}=0.486 ; \mathrm{p}=0.201$, and $\mathrm{p}=0.454)$.

Sonuç: Laparoskopik histerektomi, düşük komplikasyon oranları ve yüksek hasta memnuniyeti olan bir operasyon yöntemi olmasına rağmen, artan cerrahi deneyimin her zaman iyi perioperatif sonuçları garanti etmediği unutulmamalıdır.

Anahtar sözcükler: Deneyim, histerektomi, laparoskopik, pelvik ameliyatı, vajinal histerektomi 


\section{INTRODUCTION}

Today, hysterectomy is one of the most frequently used surgical treatments 1 . Hysterectomy is performed primarily by three methods: these methods are abdominal, vaginal, or minimally invasive methods. Laparoscopic hysterectomy (LH) caused less blood loss, reduced wound infection, short hospitalization time, and less labor loss; these are the main factors leading to a rapid increase in its popularity ${ }^{2,3}$.

It is recommended that minimally invasive methods should be applied in hysterectomies due to benign reasons ${ }^{4}$. Although laparoscopic procedures are often used in patients circumstances of whom are requiring urgent intervention, such as Tubo-ovarian abscess and adnexal torsion ${ }^{5,}{ }^{6}$, it is obvious that most gynecologists are not satisfied with the percentage of LH operations and want to increase this rate ${ }^{7}$.

Factors such as the patient's age, parity number, and previous history of pelvic surgery should be taken into account in order to ensure a successful and safe $\mathrm{LH}^{8,9}$. However, the most important factor in the low LH ratio compared to abdominal hysterectomy $(\mathrm{AH})$ and vaginal hysterectomy $(\mathrm{VH})$ is the lack of surgical experience .

Studies have shown that education and training for $\mathrm{LH}$ reduce the complication rate and emphasizes the importance of the learning curve.

Defining the learning curve for LH is necessary to guide. We aimed to define our learning curve in LH, which is our first clinical experience.

In our study, the perioperative results of the first $30 \mathrm{LH}$ operations and those of the second $62 \mathrm{LH}$ operations, which consisted of patients with similar basic demographic characteristics, were compared.

\section{MATERIAL AND METHODS}

A total of 92 patients who were operated between September 2013 and June 2015 in our clinic and Gynecology were included in our study.

All operations were performed by the same surgeon. A signed consent form was obtained from all patients prior to the operation. Bimanual pelvic examination, transvaginal ultrasound (USG), cervicovaginal smear, and endometrial sampling were performed to all patients prior to surgery. Patients with malignancy were not included in the study. Diagnostic cystoscopy (CYS) was performed with LH with or without adnexa. The patients' data were analyzed retrospectively from the records of the Faculty of Medicine Education and Research Hospital.

In our study, patients were grouped as being those under 55 years of age and those 55 years old or older. Those who had no menstruation for one year were accepted being menopausal patients. The patients who have been considered as the history of pelvic surgery are the patients with previous cesarean section and pelvic, genital organs or pelvic, genital organs adjacent to the gastrointestinal tract / urinary tract surgery

One gram of cefazolin was administered to all patients as prophylactic antibiotics preoperatively. The patients were given aqueous diet for 24 hours before the operation. Oral laxatives were given one day before the operation and rectal enema at 8-hour intervals. The time between the first incision made to the skin and the last suture applied when the skin was closed defined as the duration of the operation in minutes (min). The change between the preoperative hemoglobin (Hb.) Value and the $\mathrm{Hb}$ value at the 6th hour postoperatively was called delta $\mathrm{Hb}$ (gr / dl). Major vascular injuries, peritoneal or postoperative period, gastrointestinal system and urinary tract trauma, operation return to $\mathrm{AH}$, and the need for reoperation for any reason were accepted as major complications. The hospitalization period was recorded in days. Patients who did not need opioids had normal defecation, spontaneous micturition, and with no mobility were discharged.

Group 1 was the first 30 patients to be performed by the same surgeon after LH operation was started first. Group 2 was formed with 62 patients who were operated on after the first 30 patients. Both groups were compared for $\mathrm{LH}$ operation results.

\section{Operation technique}

All operations were performed under general anesthesia and in the neutral lithotomy position. The bladder was catheterized. A nasogastric tube was applied to all patients. The maneuver, which is completely seated in the vaginal fornix, is placed in the uterine cavity.

Pneumoperitoneum is provided by Verres needle applied from the umbilicus. A $10 \mathrm{~mm}$ telescope was then inserted into the trocar sheath. $5 \mathrm{~mm}$ trocar sheaths were placed in both hypochondria. The device was placed on the palmer point, and the device was operated with tissue fusion technology. $5 \mathrm{~mm}$ diameter trocar arm placed on 
both sub-dials and $5 \mathrm{~mm}$ diameter dissector and retaining forceps were placed. The operations were performed by increasing the uterine pelvic floor with the help of manipulator. Tissue dissection was performed on both sides in the round ligament, uterooverian or infundibulopelvic ligament with tissue fusion technology to provide hemostasis.

All surgical procedures were performed closest to the uterus. The anterior and posterior leaves of the peritoneum were opened to reveal uterine artery traces. The tissue fusion technology device coagulated the uterine arteries. The peritoneal folds and bladder were removed and dissected from the uterus and upper vagina. From the level of the vaginal fornices, all the vaginal walls were circularly separated from the cervix by a monopolar L-shaped needle. The surgical material was taken out through the vagina. The vaginal cuff is sutured vaginally or laparoscopically with late fusible sutures. Then, a rigid cystoscope was used for diagnostic cystoscopy. All walls of the bladder were systematically observed. Cystoscopy revealed jet flow from both ureteric openings.

\section{Statistical analysis}

Mean, standard deviation, and ratio values were used in descriptive statistics of the data. Independent sample t-test was used to evaluate quantitative data. All data recorded in SPSS v21.0. $\mathrm{p}<0.05$ were considered statistically significant.

\section{RESULTS}

The mean age of patients included in our study was $50.29+/-7.62$ years. The mean number of parity was 2.9 (min.0- max.9). Seventeen patients (18.4\%) had undergone previous pelvic surgery. Of the patients in our study, $30(32.6 \%)$ were in menopause. The most common indication for operation was myoma uteri detected in 39 patients (42.3\%). The average operation time was 138.21 +/- 34.56 min. The major perioperative complication was detected only in $4(4.6 \%)$ patients. One patient $(1.1 \%)$ case was required reoperation, and 3 patients had trauma $(3.5 \%)$. The mean delta $\mathrm{Hb}$ value was $1.46+/-1.39 \mathrm{~g} / \mathrm{dl}$ in all patients with LH. None of the patients developed postoperative febrile morbidity.

No statistically significant difference was found in terms of age, median parity number and past history of pelvic surgery among the patients in Group 1 and Group $2(\mathrm{p}=0.845 ; \mathrm{p}=0.266$, and $\mathrm{p}$ $=0.796)$.

There was no statistically significant difference in terms of operation time (min.), Delta $\mathrm{Hb}$ (gr / dl), duration of hospitalization (day) and complication rate among the patients in Group 1 and Group 2 (p $=0.198 ; \mathrm{p}=0.486 ; \mathrm{p}=0.201$, and $\mathrm{p}=0.454)$ (Table 1). 
Table 1: Comparison of age, parity number, pelvic surgery history, operation time, delta hb, hospitalization time and complication rates in both groups

\begin{tabular}{|c|c|c|c|c|c|c|c|}
\hline & Group & $\mathbf{N}$ & $\overline{\mathbf{X}}$ & SD & df & $\mathbf{t}$ & $\mathbf{p}$ \\
\hline \multirow{2}{*}{$\underset{<}{\infty}$} & Group 1 & 30 & 50.57 & 4.57 & \multirow[b]{2}{*}{90} & \multirow[b]{2}{*}{0.441} & \multirow[b]{2}{*}{0.845} \\
\hline & & 62 & 50.34 & 5.49 & & & \\
\hline \multirow{2}{*}{ 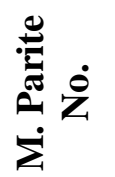 } & Group 1 & 30 & 4.13 & 2.40 & \multirow[b]{2}{*}{90} & \multirow[b]{2}{*}{0.062} & \multirow[b]{2}{*}{0.266} \\
\hline & Group 2 & 62 & 3.44 & 2.98 & & & \\
\hline \multirow{2}{*}{ 总 } & Group 1 & 30 & 1.80 & 0.41 & \multirow{2}{*}{90} & \multirow{2}{*}{0.610} & \multirow{2}{*}{0.796} \\
\hline & Group 2 & 62 & 1.82 & 0.38 & & & \\
\hline \multirow{2}{*}{ 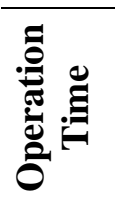 } & Group 1 & 30 & 131.51 & 26.35 & \multirow[b]{2}{*}{90} & \multirow[b]{2}{*}{0.118} & \multirow[b]{2}{*}{0.198} \\
\hline & Group 2 & 62 & 141.45 & 37.73 & & & \\
\hline \multirow{2}{*}{ 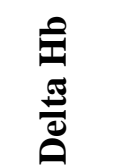 } & Group 1 & 30 & 1.82 & 1.18 & \multirow[b]{2}{*}{90} & \multirow[b]{2}{*}{0.067} & \multirow[b]{2}{*}{0.486} \\
\hline & Group 2 & 62 & 1.66 & 0.99 & & & \\
\hline \multirow{2}{*}{ 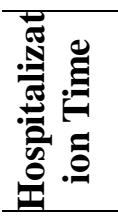 } & Group 1 & 30 & 2.90 & 1.60 & \multirow{2}{*}{90} & \multirow{2}{*}{0.0951} & \multirow{2}{*}{0.201} \\
\hline & Group 2 & 62 & 3.34 & 1.49 & & & \\
\hline \multirow{2}{*}{ نَّ } & Group 1 & 30 & 1.93 & 0.25 & \multirow{2}{*}{90} & \multirow{2}{*}{0.136} & \multirow{2}{*}{0.454} \\
\hline & Group 2 & 62 & 1.97 & 0.18 & & & \\
\hline
\end{tabular}

\section{DISCUSSION}

The factors affecting the results of $\mathrm{LH}$ due to the benign reasons were investigated in many studies. In our study, our results, such as total major complication rate, operation time, delta $\mathrm{Hb}$ value, and hospitalization time were similar to the other studies in the literature. Brummer et al. during operation $1000 \mathrm{ml}$. The rate of blood loss was $3 \%$, and the rate of urinary tract trauma was found to be $0.3 \%^{8}$. $\mathrm{O}$.Hanlan et al. It has been shown that the rate of return to the abdominal or vaginal approach is less than $1 \%$ due to any problem in hysterectomies performed by minimally invasive methods and the mean time of operation for $\mathrm{LH}$ is $132+/-55 \mathrm{~min}$ and $1.4+/$ 0.9 days ${ }^{10}$. Chopin et al. while the average operation time is $120 \mathrm{~min}$. and the duration of hospitalization was found to be 3 days ${ }^{11}$. Malinowski et al. They found the delta $\mathrm{Hb}$ value as $1.29 \mathrm{~g} / \mathrm{dl}$ in $\mathrm{LH}^{12}$. In our study, the operations performed by the same surgeon within a period of 21 months were evaluated.

Many studies have shown that the complication rates in LH increase with age and the operation results are adversely affected ${ }^{8}$. It is known that the laxity of the vaginal membrane increases with delivery ${ }^{13}$. 
In women with low parity, it has been shown to be a more difficult procedure to exclude the operation specimen through vagina ${ }^{14}$. It has been previously established that the number of parity and the length of hospitalization after $\mathrm{LH}$ is reduced ${ }^{15}$.

In our study, there were no statistically significant differences between the first 30 patients and the remaining 62 patients in terms of patient age, parity number, and pelvic surgery. The lack of the effect of previous pelvic surgery on the results of our study may be due to the maturation of the surgeon's learning curve, but Twijnstra et al. reported that pelvic surgery adversely affects LH results ${ }^{9}$. Ayala-Yáñez et al. reported that pelvic surgery increased the risk of major complications in $\mathrm{LH}^{16}$.

In many studies examining the factors affecting perioperative and postoperative outcomes, the experience of headache was focused on 12. Duration of operation, perioperative complications, and adverse postoperative outcomes are generally predicted to decrease based on the surgeon's growing experience ${ }^{9}$. It has been advocated that the experience of the surgeon is increased with every LH performed, and consequently, there is a significant improvement in operative outcomes after $30 \mathrm{LHs}$ in particular 13. O. Hanlan et al. The operative time, perpetual blood loss, and duration of hospitalization were significantly reduced with the increase of surgical experience ${ }^{10}$. Lower urinary tract trauma has been shown to decrease with increasing experience in $\mathrm{LH}^{13}$. In our study, age, parity number, and previous history of pelvic surgery were compared with those of the first $30 \mathrm{LH}$ and the other $62 \mathrm{LH}$. However, the operation time, delta $\mathrm{Hb}$, and hospitalization time were not changed after the first $30 \mathrm{LH}$. Our major complication rate was similar between the first 30 patients operated and the other group patients. Twijnstra et al. similar to our study, increased perioperative blood loss with increasing experience, but LH did not guarantee good operation results ${ }^{9}$. The reason for this is that the surgeon chooses the laparoscopic approach in patients who may have more successful results with $\mathrm{AH}$ or $\mathrm{VH}$ as the number of operations increases.

Although LH is an opacity method with low complication rates and high patient satisfaction, it should be kept in mind that increased surgical experience is not a factor that positively affects the complication rates and operating results.

\section{Declaration of conflicting interests:}

The authors declared no potential conflicts of interest with respect to the research, authorship, and/or publication of this article.

The submission has not been previously published, nor is it before another journal for consideration

The authors declare institutional and financial support.

\section{REFERENCES}

1. İsaoglu Ü, Yılmaz M, Delibaş İB, et al. The evaluation of histopathologic diagnosis in specimens of hysterectomy. Abant Med J 2013; 2 (2): 91-4.

2. Nieboer TE, Johnson N, Lethaby A, et al. Surgical approach to hysterectomy for the benign gynecological disease. Cochrane Database Syst Rev 2009; 8 (3): CD003677.

3. Kluivers KB, Opmeer BC, Geomini PM, et al. Women's preference for laparoscopic or abdominal hysterectomy. Gynecol Surg 2009; 6 (3): 223-8.

4. AAGL Advancing Minimally Invasive Gynecology Worldwide. AAGL position statement: route of hysterectomy to treat benign uterine disease. J Minim Invasive Gynecol 2011; 18 (1): 1-3.

5. Cengiz H, Dağdeviren H, Ekin M, et al. Surgical management of Tubo-ovarian abscess: Results of retrospective case series. J Clin Exp Invest 2012; 3(4):4636.

6. Erkal N, İsenlik BS, Çağlar $M$, Sahillioğlu B, Kumruet S. Management of adnexal torsion. J Clin Exp Invest 2014; 5 (1): 7-11. 
7. Englund M, Robson S. Why has the acceptance of laparoscopic hysterectomy been slow? Results of an anonymous survey of Australian gynecologists. J Minim Invasive Gynecol 2007; 14 (6): 724-8.

8. Brummer TH, Jalkanen J, Fraser J, et al. FINHYST, a prospective study of 5279 hysterectomies: complications and their risk factors. Hum Reprod 2011; 26 (7): 1741-51.

9. Twijnstra AR, Blikkendaal MD, van Zwet EW, et al. Predictors of successful surgical outcome in laparoscopic hysterectomy. Obstet Gynecol 2012; 119 (4): 700-8.

10. O'Hanlan KA, Dibble SL, Garnier AC, Reuland ML. Total laparoscopic hysterectomy: technique and complications of 830 cases. JSLS 2007; 11 (1): 45-53.

11. Chopin N, Malaret JM, Lafay-Pillet MC, et al. Total laparoscopic hysterectomy for benign uterine pathologies: obesity does not increase the risk of complications. Hum Reprod 2009; 24 (12): 3057-62.
12. Malinowski A, Makowska J, Antosiak B. Total laparoscopic hysterectomy-indications and complications of 158 patients. Ginekol Pol 2013; 84 (4): 252-7.

13. Mäkinen J, Johansson J, Tomás C, et al. Morbidity of 10110 hysterectomies by type of approach. Hum Reprod 2001; 16 (7): 1473-8.

14. Petros PP. The intravaginal slingplasty operation, a minimally invasive technique for cure of urinary incontinence in the female. Aust N Z J Obstet Gynaecol 1996; 36 (4): 453-61.

15. Yavuzcan A, Çağlar M, Üstün Y, et al. The effects of age, parity, menopause and previous pelvic surgery on the outcomes of laparoscopic hysterectomy. Düzce Tip Dergisi 2013; 15 (3): 22-5.

16. Ayala-Yáñez R, Briones-Landa $\mathrm{C}$, Anaya-Coeto H, Leroy-López L, Zavaleta-Salazar R. Total laparoscopic hysterectomy: descriptive study of institutional experience with 198 cases. Ginecol Obstet Mex 2010; 78 (11): 605 11. 